\title{
THE PROSPECTS OF COOPERATION IN A BIPOLAR WORLD
}

\author{
HAROLD D. LASSWELL*
}

$A^{s}$

WORLD politics freezes into a bipolar mold, policies in every sphere of human activity are affected by calculations of the relative strength of America and Russia. A good crop in Western Germany is chiefly evaluated, not in economic or humanitarian terms, but according to its effect upon Soviet-American power. The question whether Italy is to receive economic assistance is entangled with estimates of how the economic recuperation of the Italian peoples will affect the spread of communism. Whether Koreans or Chinese are to have medical aid becomes subordinated to the Russo-American balance of power in Asia. Every expansion of population, every decline in the death rate, every upswing in production, every drop or rise in the standard of living, every amelioration in the respect position of the colored peoples, every advance in scientific knowledge, every radio broadcast, every movement of students or traders or tourists or displaced persons across frontier lines, every addition to transportation facilities (by air, sea, or land), every movement of raw materials, foodstuffs, semi-processed products, machine tools or consumer goods: In a word every social change is promptly weighed in the scale pans of power and responded to accordingly.

The prospects of cooperation depend upon whether the demands, expectations, and identifications of Russians and Americans can be modified to include cooperation. ${ }^{x}$

It is no exaggeration to say that World War I was a traumatic shock to the West, mainly because it happened at all. Business civilization had a dream of its own, the legend of a peaceful, prosperous, and fraternal future. It was the dream told round the world by Cobden, who spoke of the perfectibility of man as the peoples of the earth learned to buy and sell freely in One Big Market.2

The businessman's utopia has not been unchallenged; and the princi-

* Professor of Law, Yale Law School.

₹ All perspectives are conveniently divisible into demands, which are preferences and volitions, expectations, which are assumptions about past-present-future, and identifications, which include the symbols that refer to persons or groups. For more detail see Lasswell, World Politics and Personal Insecurity (r935).

2 See Hobson, Richard Cobden, the International Man (Igrg). 
pal challenger was Marx, who though at one with Cobden in prophesying the imminent progress of mankind, foretold the realization of freedom by catastrophe, not evolution. The Marxist forecast gained in influence as it grew in plausibility: Had it not predicted the growth of monopoly? the recurring crises of boom and bust? the rise of a class-conscious movement of protest demanding radical means of ushering in the free man's commonwealth?

The trauma of I9I4 was in the true sense of the word a psychic shock, since it was shocking precisely because it fulfilled expectations largely denied or suppressed. ${ }^{3}$ The ideology of the ruling elements of the West offered no coherent explanation of big-scale war or big-scale monopoly. And yet a counter-ideology had been shouted from the soapboxes and even the parliaments of Europe for decades, demanding at least a rational answer.

Today, after a succession of shattering blows, and in the midst of a crystallizing bipolar pattern of global politics, pessimism about cooperation is as universal as the optimism of former decades. The skeleton of war can no longer be kept in the closet; it has the run of the press. The fact of conflict is no longer glossed over by the amenities of diplomatic doubletalk. (The outspokenness of Soviet diplomats has raised public vituperation to a diplomatic folkway.)

And so we ask: Is the pessimism of today as overdone as the optimism of yesterday? Can there be cooperation in a bipolarizing world?

\section{A DEVELOPMENTAL CONSTRUCT OF THE FUTURE}

Let us begin by imagining the future if cooperation wins. By requiring ourselves to think through this possibility, we make it necessary to consider the factors affecting war, not "in general," but in the context of events in which we live. (It is assumed in this discussion that we approve of policies that aim to extract as much safety, prosperity, and decency as possible from the historical circumstances in which we are caught.) We begin with events since the bomb, and postulate four periods: Period I. Weapon supremacy of the U.S. Period II. Reports of the U.S.S.R. weapon parity become more credible. Period III. Weapon Parity Attained. Period IV. The Turning Point.

It is apparent that we are passing out of the first into the second period, A.B. During phase one, which we are completing, a leading characteristic was universal recognition that the U.S. had weapon superiority in the newest instruments of warfare.

${ }^{3}$ See Freud, Inhibition, Symptom and Anxiety (1927). 
Starting first with the Russian élite, their behavior during the first period was intelligible if we postulate the following structure of expectations on their part: The U.S. is unlikely to use the bomb in the immediate future because of several factors: Residual enthusiasm among the American people for the heroic resistance of Russia to Nazi aggression; overwhelming popular demand for the return and demobilization of most of the armed forces; enthusiasm to "get the government out of business"; continuing hatred of the Germans; a temporary stabilization of capitalism during the early years of reconstruction; and the avoiding of mass crises of unemployment. An effective system of international inspection would authoritatively confirm rumors of our inner weaknesses (both material and psychological), and increase the likelihood that the ruling elements in the U.S. would take the initiative in attacking the Soviet Union (seeking to liquidate the center of world revolutionary menace to the bourgeois world). By protracted negotiation it will be possible to prevent the issue of effective control from coming to a head.

The behavior of the U.S. élite during the same period is intelligible if we postulate the following expectations on their part: Even if desirable, the American people are unwilling to wage a preventive war against Russia; there is a possibility (however slight) that a basis for effective atomic control can be laid by negotiation (even apart from a general settlement of Russo-American relations); if the negotiations do in fact fail, the unity of our people will be increased in favor of a policy which "contains" Russia in a military sense, while fostering the long range probability of peace by aiding the recovery and prosperity of the accessible peoples of the globe.

Today we are entering a second phase whose outstanding expectation can be summed up in this way: Reports of weapon parity with the U.S. on the part of the Soviet Union will be treated as more and more credible.

If this second phase is navigated without World War III, third period expectations will be: The U.S. and the U.S.S.R. have weapon parity.

\section{THE PROSPECTS OF A TURNING POINT}

If peaceful cooperation is to succeed in the long run, there will be a fourth period in which the expectation of war begins to diminish, and the meagre trickle of pacific contact between the two polar camps will swell into an enlarging stream, inaugurating a new era of peaceful association in which the world community makes direct progress toward a more perfect community of free men.

In constructing a speculative model of the fourth period, we begin by 
considering two subdivisions, one before and one after the turning point. The first subphase can be characterized in terms of dominant expectations:

I) "Push-button" war may begin any time. This implies that world politics is crystallized in two sharply delimited groups of states that watch each other in full awareness of the possibility that war may begin at any moment.

2) If the opponent makes a sudden, unprevented attack, he can inflict severe damage. Weapon parity, such as we assume for the two opposing camps, does not imply formal equality of destructive potential. We postulate no more than the recognition of the existence of capacity to impose severe damage.

3) If the opponent makes an attack, severe damage will be inflicted on him. Since potential antagonists will have one another under continual surveillance, a sneak attack, even if undetected, is not likely to deliver a knockout blow, but rather to set off a counterblow mechanism.

4) If the opponent initiates an attack, it may be possible to anticipate him by launching a preventive attack. This takes into account the possibility that one's system of surveillance can be so efficient that the enemy can be hit before he consummates an intended assault.

5) If one decides to initiate an attack upon the opponent (in the hope of putting an end to the high level of continuing tension), the opponent may initiate a preventive attack instantly, thanks to his system of surveillance; even if he delays, he can (as assumed above) inflict severe damage. This discounts the possibility of escaping the enemy's surveillance sufficiently to deliver a surprise knockout blow.

6) The élite of the opposing power expects to retain its ascendancy at home without using war as a means of diverting revolutionary tension against a foreign enemy; the élite is also aware that the damage resulting from war would be grave enough to endanger the retention of power, as well as the enjoyment of other values. To postulate that élites are not threatened at home at this stage means that they have solved the problem of adjusting their people to the way of life called for under garrison conditions. Everyone has become accustomed to live with the cloud of war on the horizon, and to justify special demands in the language of strategic advantage. Institutions have been adapted to the maintenance of high levels of productive employment, and to the prevention of crises of mass discontent from whatever cause. Further, it is postulated that the ruling elements of the two garrisons recognize that war can mean, not one sur- 
viving and triumphant Rome, but two Carthages. ${ }^{4}$ If Russia and America knock each other out (or inflict shattering reductions of power upon each other) the power vacuum will be gradually occupied by the surviving peripheral powers (unless, of course, all life is annihilated).

7) The elite of the opposing power can prevent unauthorized acts of war. This postulate refers to the possibility of detecting and restraining those paranoid persons or cliques who may privately initiate acts of aggression.

8) Our élite can prevent unauthorized acts of war. This refers to circumstances which correspond to seven (just above). Given the foregoing structure of expectation, the dominant policy demand will be, "Don't make war now" (since war would be expected to leave the élites worse off than no-war).

We now come to the turning point itself. The structure of expectation can be described in the following terms:

I) The élites of the two garrison camps recognize the high cost of preparing for a war that, if it comes, will endanger their power. Instead of diverting human resources into armament, it will be obvious that the standard of living and the level of scientific knowledge, for instance, can be improved.

2) The élites of the two garrisons recognize that neither one depends upon war or the threat of war to retain power at home. According to Marxist doctrine war is inevitable because of the internal instability of capitalism, and the desire to divert explosive insecurities against the external enemy. We postulate that the non-Russian world learns how to avoid crises of mass unemployment, and in this way undermines the doctrinaire expectation just described.

3) Both élites can gain by agreeing to limit and reduce arms, and by inaugurating modes of administrative control that maintain mutual confidence. It is postulated that both élites achieve enough confidence in their own strength to permit disclosure.

FURTHER DETAII ON THE SECOND AND THIRD PERIODS

The foregoing sketch of the "turning point" enables us to fill in the gap between the present and the fourth period (on the assumption that war is avoided throughout).

\section{IN THE UNITED STATES}

As estimates of Russia's expanding weapon strength become more credible, the America-centered world grows less and less secure. Military (1946).

4 Lasswell, The Interrelations of World Organization and Society, 55 Yale L.J. 889, 897 
considerations are given increasing weight in calculations of official and private policy. Hence the resources of the nation are allocated in ways that are assumed to improve national security.

This involves an accelerated tempo of governmentalization. In part this comes about because of the vast expenditures which are deemed essential for the military establishments. Partly, too, the government will be turned to for funds as private investors, appalled by the high probability of war, fail to provide the funds needed to maintain high levels of productive employment (and it is generally recognized that the nation would collapse politically if it permitted mass unemployment). The expansion of government is also fostered by the demand to check on the loyalty of everyone in public life, and to an increasing extent, in any sphere of activity whatever. Scrutiny by the police of government employees will be broadened to include all who receive contracts and subcontracts from public funds, and since an ever increasing percentage of American industry, education, and research will depend upon government money, police surveillance will become a regular feature of American life, and denunciations will become a more common means of personal advancement over rival scientists, educators, workers, professional men, business managers, government administrators, soldiers, and police.

Governmentalization carries with it the centering of decision-making in Washington and the relative decline of state and metropolitan government. As the fiscal reins are gathered in national hands, the grant-in-aid and the direct allocation of material become major means of subordinating local plans to central purposes. Local affairs are seen in the perspective of the entire American security zone, which brings in Canada, Central and South America, and whatever spheres in Europe, Africa, Asia, and the islands of the Pacific are part of the America-centered garrison. Bases are ringed around the globe for the double purpose of surveillance and retaliation; and facilities are decentralized according to a centrally determined program for reducing the vulnerability of static targets.

Regimentation is a concomitant of the governmentalizing process (using the term to refer to the invasion of former zones of privacy by government). Not only are organized private activities dominated by government; private life is encroached upon by police surveillance, by the drafting of men for military service, by the restricting of free movement in the interest of security (for the enlarging list of military reservations).

Democracy also declines, especially as enlightenment dwindles away. In the name of security, less and less information is allowed to pass through the mass media of communication to the public for comment, 
discussion, petition, pressure group formation, or party action. At first the owners and managers of the media institute a "voluntary censorship," a censorship made more palatable by the bribe of "inside information" received on the understanding that it is not to be disseminated further "for security reasons." Public forums become devoid of informed content, save for local matters. Criticism, growing less informed, more parochial, less unified, and more suspect for "unpatriotic" content, declines in prestige and power.

Alongside these transformations occurs the rise of the soldier-policeman at the expense of the civilian skill groups. The governmentalizing process carries with it the decline of groups whose power depends upon free markets, free forums, free pressure, and party activity. The businessman becomes a contractor and subcontractor of government dependent upon administrative decisions, rather than free bargaining to obtain materials, labor, transportation, designs, location, credit, and most of the other items for which the free enterpriser takes responsibility. Party propagandists and administrators decline as the party system loses effectiveness. The propagandists and the owner-administrators of pressure groups or mass media of communication also drop off in influence.

Initially the one who benefits from the shift from private to government activity is the civilian administrator. But civilian authority and control are steadily whittled away by the soldier-policeman, whose distinctive nuclear skill is violence, not propaganda, bargaining, or civil administration. When the strategic dimensions of every public expenditure loom, the soldier is turned to for advice, and the policeman for loyalty information. Consulted more often, the soldier-policeman participates more fully in top level decisions. Having a more and more complete monopoly of "security" information, these elements improve their power position by withholding knowledge from civilian administrators, and from Congress, the parties, pressure groups, and owner-editors of mass media. Civilian control blacks out gradually as the beams of intelligence grow dim, first for the public at large, and eventually for the civilians who are nominally in power. As the community becomes more apprehensive of the dependability of its officials and of the neighbors, the results of police espionage are permitted to weigh in the evaluation of loyalty, even when such results are incompletely disclosed. Traditional means of protecting the privacy of individuals against official encroachment are gradually rendered inoperative. The political police become more important, rivaling the soldier for the top role in the affairs of the garrison state.

Personnel is more frequently recruited from soldier-police elements, 
eventually creating a self-perpetuating bureaucracy which relies upon "dependable elements" from the families and satellites of the soldier-police bureaucrats themselves.

Since the changes envisaged in this sketch are not expected to come all at once (or even to be carried to their "logical," i.e., "thinkable" conclusion), they are spread over several years, which enables the deep-seated objections springing from American tradition to be overcome piecemeal. It is conceivable that modern skills of management will be applied, with much success, to the task of reducing the dislocations incidental to the transformations here outlined. Seeing the seriousness of the "fifth column" danger from disaffection within the community, continuous efforts will be made to remove the discriminations which are a permanent source of insult to the self-esteem of ethnic groups within the United States. In the United States security zone, the obvious advantage of receiving mass support will bring about continual effort to improve the position of the masses.

IN THE U.S.S.R.

The Soviet Union, in the meanwhile, has adjusted to the second and third periods with far less sweeping changes than the United States, since governmentalization has prevailed in the U.S.S.R. for many years. Regimentation, centralization, and despotism are not new; and the institutions of the free market, free forum, and free party system have never struck firm root.

None the less, the political picture in the Soviet Union will not be entirely static. Civilian control, for example, is a basic principle of Soviet policy, and the party has successfully fought to maintain the ascendancy of the party over the state, including all such skill specialists as soldiers and police, and such organs as the army and the police services. The police have achieved their present and prospective eminence in the struggle of the party élite against rival cradles of power, notably the Red Army. Mastery of Marxist-Leninist-Stalinist dogma is one instrument of the party in the inner battle for control; and we can foresee the continuation of the struggle to bring about the selection and promotion of officers and administrators who demonstrate their doctrinal competence and discipline to the satisfaction of the party. At the same time the primacy of the party is undermined by tendencies which, unless kept in perpetual check, will overthrow it. Specialists on military matters typically are so devoted to the preparation and rehearsal of war plans that they resent the time "lost" on refresher courses on party dogma; and they resent the attempt of party police, and other party organs, to maintain effective control over the 
decision-making spots in the Red Army. Many other specialists, absorbed in fascinating and responsible tasks, resent the doctrinaires and propagandists. Scientists, engineers, and other production men belong to the "annoyed," tending to reject highflown phrases as cant, and the cantors as windbags.

The effect of these and related factors is to bring about the "dilution" of doctrinal fanaticism among party recruits. Members are taken in, less for doctrinal purity and agitational ability, than for reasons of family security, personal congeniality, and individual ability. The central leadership is subject to chronic danger from "grass roots" leaders who develop what we may call proto-constituencies inside and outside the party cadres. These proto-constituencies develop as spokesmen rise to champion the claim to a better deal for this or that collective farm, industrial, professional, trade union, or local element in the population. There is a steady undertow of unacknowledged pressure from individuals and small groups who want "more now" rather than in the distant future, and who therefore are in favor of larger expenditures on diet, more commodious houses, larger rest homes, longer vacations, improved medical care, and other "real income" items. The argument takes the form of justifying claims for higher nominal and real wages to be paid to those who do the dangerous or the vital jobs, or who "sacrifice" by spending long years at school. Totalitarian states, of course, are experienced in the use of administrative devices which are designed to prevent the growth of subleaders with tacit (or what we have called proto-) constituencies. Officials are switched here and there in order to forestall the formation of local ties, and to keep the individual totally dependent upon the central administration. Occasionally, however, cleavages reach within the inner circles of the party élite, precipitating acute crises which have thus far ended with the defeat (and even the liquidation or suicide) of top spokesmen for the peasants, trade unions, or other components of Soviet society.

As a means of counteracting incipient trends toward de-governmentalization, decentralization, and democracy, many tactics are at the disposal of the top leadership. Among the available maneuvers the most dramatic instrument is the party purge, which is a drastic review and expulsion of "undesirable" elements. Actually the purge is one of the cyclical movements which is distinctive of the mass party dictatorship: It is a means by which a threatened pattern of power (a threatened equilibrium) is restored. Michels christened the purge-dilution-purge cycle the "accordion rhythm" of mass party dictatorships. ${ }^{5}$ Through the cumulation of

5 Michels, Sozialismus und Fascismus in Italien (1925); Michels, Italien von Heute (1930). 
private incentives the party membership expands, diluting the ideological intensity of the organization; startled by incidents which reveal the danger of losing or sharing power, the central élite suddenly presses the party together. (Michels does not develop his metaphor to the point of specifying the nature of the sounds which are emitted at each phase of the cycle; given the prevailing ideological pattern, even this can be done.)

We have postulated that the Soviet Union will grow stronger as the years pass (measured in terms of numbers, industrialization, modern weapon parity), and the living standard can slowly be allowed to rise, despite the outlay for armament. The purge will become less necessary as the deprivations to which the community is subjected become less severe.

\section{ESTIMATING PROBABLITY}

The preceding pages have outlined a hypothetical course of events in future world politics in which war is avoided, and global cooperation is eventually restored and extended. What is the likelihood that global developments will follow this pattern?

In evaluating the "construct" we need to consider the analyses and findings of the psychological and social sciences. Phrasing the matter in the most general way, we can say that effective cooperation is a variable in the social equilibrium of the world community which depends upon (and in turn acts upon) other variables, especially upon the expectation that policies of cooperation will yield a higher net return than non-cooperation. Net return is appraised in reference to such values as deference, income, and safety (two important deference values are power and respect). ${ }^{6}$ Values are sought for the benefit of the self, which includes, besides the primary ego, all persons who are given the same treatment as the ego (e.g., family, neighbors, class, nation, party). The developmental picture portrays a world equilibrium in which the structure of expectation and demand remains sufficiently strong to sustain the demand to cooperate in competition with the demand to break off cooperation and resort to war. Furthermore, it is postulated that the equilibrium is maintained although the process works itself out through certain institutional features, some of which exist during all periods, others during some periods. Bipolarity, for example, is postulated throughout. Bipolarization, which is transition to a crystallized bipolar pattern, is said to be completed during the second period. The concentration of power inside each state involves the continuous denial of freedom in Russia, and the curtailment of freedom else=

\footnotetext{
${ }^{6}$ Concerning values, see Lasswell and McDougal, Legal Education and Public Policy: Professional Training in the Public Interest, 52 Yale L. J. 203 (r943). Reprinted in Lasswell, The Analysis of Political Behaviour; An Empirical Approach, in The International Library of Sociology (Mannheim ed., I948).
} 
where. It is postulated that ideological differences diminish as the turning point is approached. Are there rational grounds for holding that it is possible to accept these institutional postulates, and also to give credence to the possibility of avoiding war? We examine each constitutional feature in turn in order to estimate the present state of knowledge concerning its relation to cooperation or war.

\section{BIPOLARITY AND THE GENERAL THEORY OF BALANCE}

Bipolarity is one of the several patterns occurring in political arenas, where it can be compared with unipolarity, pluripolarity, and multipolarity. The unipolar pattern is found in situations in which one state attains overwhelming dominance, whether the state is "universal" or not. When the pattern is pluripolar, a few states dominate. Multipolarity occurs when only small states exist.7

When we talk of a bipolar structure of global power, we are referring to the globe as a military, not a civic arena. Since power is a decision-making process, the form of the process is conditioned by the expectations which prevail about the manner in which decisions are made. When the expectation is that decisions will be imposed by force, we speak of a military arena. A civic arena, on the other hand, is characterized by the expectation that decisions will be registered peacefully and with little thought of the need of relying on force to back them up. Putting the distinction more generally, a political arena is civic when the expectation of violence is low, and military when the expectation is high. The eventual aim of pacific cooperation is to transform the world community, which is now structured as a military arena, into a civic arena in which power-balancing can proceed with an eye on votes, rather than war and revolution.

Perhaps it is worth reminding ourselves that the expectation of violence, and the resulting military arena, does not imply war at regularly recurring intervals. The history of warfare, if it shows the near-universality of war as a social institution, shows with equal conclusiveness that wars do not recur "on the hour." Many countries have gone many years without coming to blows (the United States and France). Efforts to discover and demonstrate the existence of a "twenty-year" (or any other) rhythm in warfare have not been successful (although a factor in war crises can be the coming of age of a new generation after a devastating war). There is nothing about the history of the balance of power, bipolar or not, that enables us to predict with confidence the recurrence of war at regular intervals. ${ }^{8}$

An outstanding characteristic of bipolarity is that freedom of recom-

7 On the polarities consult Fox, The Super-Powers (I944).

8 The standard summaries of research on war are Wright, A Study of War (I942); Sorokin, Fluctuations of Social Relationships, War, and Revolution 352-60 (1937). 
bination is reduced to the vanishing point. Only when the diplomatic alignment is in transition toward bipolarity does a degree of freedom prevail among intermediate powers, and a state like Czechoslovakia teeters precariously on the rim of one power zone before falling one way or the other. Freedom of recombination is at a maximum in multipolar systems, as in India or Europe during periods when no great consolidations of power have lifted themselves above the ruck of tribes and principalities. Less wide than in multipolar arenas, freedom of recombination remains nevertheless a significant feature of pluripolar systems, since it is taken for granted that at least two diplomatic alignments of about equal attractiveness are open to each participant. Situated between Russia and Western Europe, Germany has for years veered first one way and then the other. The General Staff, the diplomatic corps, the publicists and other politically alert elements were usually split between advocates of an orientation East or West. The possibility of a quick shift does not disappear on the coming of war: Witness the swift recombination of Russia and Germany in World War II, and the stubborn hope of Nazi leaders that they would succeed in driving a wedge between Russia and the West. Before I9r4 Italy played with the German-Austro-Hungarian bloc until the outbreak of hostilities, and eventually gravitated into the opposing camp; in World War II the orbit of Italy was also eccentric. ${ }^{9}$

In evaluating the future the key question is: Can we regard it as established that the probability of war varies inversely with the flexibility of political recombination, and therefore is least when the pattern is multipolar and greatest under bipolar conditions? There is serious support for an affirmative answer: "The probability of war will decrease in proportion as the number of states in the system increases."Io

Recall, however, that before the rise of national states from the atomism of feudal Europe, the continent was in perpetual turmoil. The wars were "little wars," often referred to by historians as "raids" or "skirmishes." When we take into account the modest size of the population, and the incompleteness of the chronicles (full of violence as they are), we can doubt whether the arena as a whole provided a safe haven for life and limb. When the political structure of Europe became pluripolar, some of the bloodiest wars in history occurred (even though the frequency of resort to war appears to have declined). The evidence concerning bipolar systems

9 On the diplomatic history of modern times see Bemis, A Diplomatic History of the United States (rev. ed., I942); Langer, European Alliances and Alignments, I871-I890 (I93I); Langer, Diplomacy of Imperialism, I89o-1902 (ז935); Bourgeois, Manuel historique de politique étrangère (1922-26).

${ }^{10} 2$ Wright, op. cit. supra note 8 , at 755 . 
is very unsatisfactory, partly from paucity of instances, and partly from insufficient or inadequately classified data. The main defect in classification is failure to distinguish between formal and effective power (between "authority" and "control"). Thus it is customary among historians of China to treat certain periods as examples of a universal (or unipolar) state pattern. Yet there is evidence that during some of these periods, effective power followed a different pattern, which was ofter bipolar, pivoting around a Northern and Southern center. ${ }^{1 x}$

In the light of the considerations just referred to, it is reasonable to amend the proposition stated above as follows: The frequency of war varies directly, and the size of war varies inversely, with the number of states in the balancing process.

Actually there is some foundation for the view that when bipolar systems are approximately equal in strength, they are stable. Our hypothetical model underlines the expectation of "weapon parity," meaning that the élites of the Russo-American world accept the likelihood that each could do severe damage to the other in the eventuality of war. "Stability will increase," according to Quincy Wright, "as the parity in the power of states increases." ${ }^{2}$ This proposition implies that stability in a bipolar parity system may be greater than when other systems lack parity (both pluri- and multipolar arenas can have many unmatched units).

On the basis of existing analysis and knowledge, we conclude that very little can be definitively said about bipolarity in a balancing system; we can at least doubt any extreme statements about the "inherent" impact of bipolarity on war.

\section{BIPOLARIZATION: THE PERILS OF TRANSITION}

Since a firm structure of bipolarity does not come into being on the instant, but in the course of a long period of rival moves and countermoves, it is important to recognize that our picture of the future embraces an early phase of transition, and that years of transition offer many

\footnotetext{
Is For a criticism of Arnold Toynbee's material in A Study of History, see Lasswell, op. cit. supra note 4 , at $89 \mathrm{r}$.

${ }^{12} 2$ Wright, op. cit. supra note 1o, at 755 . Note that world politics can be repluralized under certain conditions of parity. If all powers (small, middle, and large) can accumulate enough destructive equipment to make almost certain the annihilation of an enemy, war will be relinquished as an instrument of policy (except for paranoid psychotics, who may be in a power position, and for whom destruction is a supreme value). This is a matter of inventing armament which can be obtained at sufficiently low cost to come within the means of every state. Under such conditions resources will probably be diverted from the making of superfluous arms to other activities; and such activities may involve cooperation across state lines. See the remarks of Jacob Viner, The Implications of the Atomic Bomb for International Relations, 90 Proc. Am. Phil. Soc. 56 (1946).
} 
perils to friendly intercourse. The emergence of bipolarity is no mere cyclical recurrence, but rather a structural change leading to a new pattern of equilibrium.

That times of transition are "times of trouble" is a commonplace of human experience and historical wisdom, and the scientific analysis of human behavior reveals many variables which account for these difficulties. Stability of response depends chiefly on stability in the structure of expectation, which is deeply, though not wholly, determined by the degree of stability in the environment. When the environment presents new and hence unanticipated problems, the adjustive capacity of the organism (individual or group) is taxed. ${ }^{\mathrm{x}}$ There is not only intellectual uncertainty about the outcome of future developments. There are unconscious anxieties generated in a condition of uncertainty, which confer cumulative intensity upon the response. In global politics whenever diplomatic, military, and other officials meet new configurations, the probability is enhanced that estimates of reality (estimates of the other fellow's conduct) will be seriously skewed. When all parties are unsure of themselves the environment is peculiarly difficult to appraise, since each provides an erratic environment for the other. Local and central officials find it difficult to judge how far to go without bringing about the war that nearly everyone may fear and wish to postpone or dispense with entirely. Diplomatic history is dotted with examples of bad judgment on the part of responsible officials acting under stress of surprise in a fog of doubt about the meaning of current developments. ${ }^{14}$ At such times the channels of intelligence are characteristically blacked out or fogged by contradictory assertions; and the rumor-ridden environment puts the heaviest imaginable burden on judgment. Deliberate instigators of crisis are in a favorable position to throw gasoline on the blaze. Hence until it is clear where the boundaries lie between the Russian and American zones, local frictions can blaze into general conflagration.

A stabilizing factor during this difficult time of transition is the extreme centralization of Soviet power. On the one hand, the continual testing of the countries around the Soviet zone proceeds in the hope of discerning

\footnotetext{
${ }^{13}$ Note the frequency of errors when individuals confront an environment where new responses must be learned. Consult Hilgard and Marquis, Conditioning and Learning (1940); McGeoch, The Psychology of Human Learning (I942).

${ }_{14}$ The Crimean War has often been called one of the "most avoidable" wars in history. Britain was involved at the very beginning in the Russo-Turkish quarrel when Colonel Rose, the British chargé d'affaires, hearing of Russia's demands from the panic-stricken Grand Vizier had to act on his own initiative and made the mistake of sending an urgent summons to the British fleet to come from Malta to Vourla. The Crimean War is covered in 2 The Cambridge History of British Foreign Policy (x922-23).
} 
the "soft" spots, and keeps the world in turmoil. On the other hand, local agents are notoriously devoid of personal initiative, holding themselves in apprehensive subordination to the all-decisive center. So long as the top Russian élite regard themselves as being too weak to engage in all-out global war, subordination of the periphery to the center is a stabilizing influence.

An unstabilizing factor is the calculation of preventive war by the party that looks upon itself as suffering relative decline. Should not the U.S. put a stop to Russian plans and acts of aggression before the modern weapons of warfare are developed to a degree that forbids such an enterprise? The following considerations operate to check the preventive war venture:

From a strategic standpoint such a war would be no "thirty-minute" campaign. Enemy territory would need to be occupied as a follow-up on the bombing of enemy targets. The military forces of America and the allies of America would occupy all Siberia and all European Russia. It would not be possible, however, to annihilate the enemy's army without doing irreparable damage to civilians in friendly countries since the Red Army, deprived of bases in Russia, can overrun cities in Western Europe which we would be loath to destroy.

At the end of active hostilities, the length of occupation would depend upon the policies to be put into effect. A relatively short period would suffice if our aim were to install machinery for the international control of nuclear energy. But during the war period, some American leaders would undoubtedly go beyond this limited objective and insist upon dismembering the U.S.S.R. and restoring private capitalism (at least of international privately owned monopolies of mines, utilities, and heavy industry). Such a program would be vehemently attacked by many other American leaders, who would assert that any attempt to disinter capitalism would transform the globe into a vast revolutionary-counter-revolutionary arena (in which America leads reaction). They would argue that any tendency to convert a "preventive" war into a "reactionary" crusade would boomerang, widening the split in American morale already stimulated by the war itself.

It is uncertain which trend of policy would win, but the champions of minimum intervention would undoubtedly be handicapped by the anticommunist, anti-Russian, anti-socialist ideology prevalent during the war, and by repressive measures put into effect by military and police authorities. Also, the conquest of Russia would not necessarily guarantee American security. There would be perpetual rumors of anti-American 
conspiracies and of new, deadly, and compact secret weapons. Our authorities would not only search for signs of subversive activity throughout Russia; they would view every nation with suspicion, wondering whether Mexico City, Madrid, or Buenos Aires harbored conspirative cells and secret laboratories devising new tools of death. Our leaders would be tempted to wage another, and yet another, "preventive" war in order to enlarge the area policed from Washington.

The shock of the first "preventive" war (the one against Russia) would have opened great cleavages among the American people, where there are many persons for whom the Soviet Union is the beacon light of humanity. The admirers of Russia are by no means exclusively recruited from racial and other "second-class" citizens of the United States. In war genuine seditionists would shock the ruling elements of America into defensive repression, tending to transform the United States (and all dependent countries) into a garrison-prison state. Each successive war of "prevention" and each successive intimidation of a "doubtful" state would alienate a new group of Americans. Since the dissenters would be distributed widely throughout the nation, the ruling groups would generate inner tension and conflict. ${ }^{15}$

In conclusion, our analysis of the period of transition underlines the precariousness of the peace while the bipolar pattern is becoming crystallized.

\section{THE DENIAL AND CURTAULMENT OF FREEDOM}

We have postulated that the social structure of the two garrison camps moves in zig-zag fashion toward a common pattern, which implies that the present denial of freedom in Russia will continue, while the progressive curtailment of freedom will occur in the American zone. Our hypothetical picture does not assume that American institutions succumb to totalitarian regimentation and despotism in a day or a decade; or, indeed, that the process is ever completed. And we do not lose sight of the probability that, as the America-centered zone enlarges, the area of freedom may be substantially widened in states where native ruling groups are cajoled or coerced into adopting measures designed to consolidate the mass basis of government.

American opinion is, in general, repelled by the thought of giving support to obsolete thrones, self-indulgent ruling families, autocratic feudal landlords, and exploitative mine owners.and industrialists. Whenever the question is raised of giving economic and military support to these

\footnotetext{
${ }_{25}$ Lasswell, op. cit. supra note 4 , at 899-900. See further Baldwin, The Price of Power 300-302 (I948).
} 
"decadent" and "reactionary" élites (for strategic reasons connected with oil or forward bases), support is subjected to a hail of criticism that reduces the speed and even the volume of the assistance. Some despotisms which the United States has aided in the past (and will no doubt assist in the future) have rejected American advice to liberalize their institutions, thinking that it is necessary for the U.S. to support them anyhow. In other cases gestures have been made, such as the passing of laws providing for a free press, free elections, and the free formation of political parties permitted to engage in propaganda. Such measures have not been accepted at face value by American officials in the past (nor will they be, in the future), but on the other hand they are not dismissed with contempt. Trained Americans are sufficiently aware of the history of constitutional and popular government in Great Britain, for instance, to recognize that documents (like the Magna Charta) wrested from one big landlord by several landlords can become the rallying symbol for further sharing of power. The prevailing official view is that our economic assistance, in addition to minimum military support, will provide for a rising standard of living throughout our security zone, and eventually create social bases for freer institutions everywhere.

Since frustration breeds protest, it requires no clairvoyance to foresee that the sacrifices entailed by a huge program of military defense, and the concomitant restriction of freedom, will result in chronic movements of protest. In the name of peace and of confidence in the basic good will of the common people of the world, leaders can rise who symbolize the pacifist trends of a business civilization. One effect of pacific agitation will be to weaken the United States, since the spectacle of pacifism and disunity affects the balance of power in many ways. One factor is that the Russian élite is schooled in that brand of dogmatic Marxism which treats pacifism as a sign of decadent social formations. Even without this particular indoctrination, however, the ruling few in despotisms characteristically look upon public protest and discussion as evidence of disunity and hence of weakness. The underestimating of democracy is a recurring disease of autocracies and tyrannies: Recall that Germany succeeded in underestimating America twice in one generation, losing two world wars in consequence. The élites of Imperial and of Nazi Germany presumed too much upon vocal expressions of pacifism, isolationism, irresoluteness, and disunity.

During the period before weapon parity is attained, war can come by inadvertence if the Russian élite miscalculates the amount of pressure to which the United States can be subjected on a given question. An element 
in miscalculation would be the overestimating of the symptoms which we have been reviewing. ${ }^{16}$ The overvaluation can lead the Russians "too far too fast" in the as yet undelimited zones between the United States and the Soviet Union. After weapon parity has been reached and the boundaries of the two-centered world have been stabilized, the threat to peace from unrealistic estimates of American democracy on the part of the Russian élite will continue. (We postulate that despite a decline in effectiveness, democratic institutions will long continue to possess vitality.)

On the American side, we must not underrate the dangers arising from the tactics by which the American élite will seek to justify enormous military expenditures, and the steady curtailment of freedom. I speak of the war scare tactic, which consists in playing up international friction so that popular expectations of imminent war are at a high pitch. As the responsible leaders of the United States cope with the task of transforming our society into a garrison state, they run afoul of the vested and sentimental interests of a business society. One obvious means of gaining support for military measures is to take advantage of tension-incidents which can be imputed to Russia. It is evident to everybody that without "the rape of Czechoslovakia" ERP would have had much tougher sledding. This war scare was not engineered by our government officials: The situation spoke for itself to American newspaper and radio correspondents. However, there will be many occasions in which the temptation to prolong a war scare will arise, quite apart from circumstances in which the party in office is trying to make itself solid in an election year. ${ }^{17}$

Inside autocracies and tyrannies the war scare is a stock device for maintaining acquiescence in a tight monopoly of power. We have previously analyzed the purge cycle; and this analysis can be extended to show how the war scare tactic is often correlated with the purge. When thousands if not millions of members have been expelled from the "party," and a shiver of fear has run down the spine of the whole population, a drama of unification is needed. ${ }^{\mathrm{x}} \mathrm{A}$ war scare turns the focus of attention

${ }^{16}$ Concerning World War II consult Shulman, Defeat in the West (I948), based on German intelligence reports. It should be observed as a counterfactor that a centralized despotism can retreat from a dangerous situation more speedily than a democratic state.

${ }^{17}$ On the influence of domestic political calculations on American foreign policy see Bailey, A Diplomatic History of the American People (3d ed., I946), which gives unusual weight to party politics and public opinion factors.

${ }^{18}$ It is a misnomer to call the monopoly "parties" of Communist, Nazi, and Fascist states by the term used where free elections are found. "Political order" is far more appropriate. We postulated that the Soviet élite will believe itself to be more secure at home as the standard of living is gradually improved, and that the technique of the war scare will become less essential. Nevertheless, the process can be long drawn out. See Lasswell, World Politics Faces Economics $56(x 945)$. 
from domestic apprehensions to a common foreign enemy, re-sentimentalizes the symbols of cohesion within a community, enables the ruling group to act as a champion of the whole, and retroactively justifies the élite in keeping the reins of power tightly in hand. The war scare and the purge can be blended, as when the purged are denounced as agents of a foreign power seeking to undermine the community. The purge trial, when a treason trial, is the ultimate in synchronization of two political patterns.

In general, the denial and curtailment of freedom, though a significant danger to peaceful evolution, is not likely to be a decisive factor in wrecking peace.

\section{CHRONIC CRISIS AND PERSONAL INSECURITIES}

We know that personal insecurities are evoked in crises, and that our hypothetical model of the future postulates high levels of expectation about the likelihood of war. True enough, tension will rise and fall, but it will not fall to the low water mark of many years past. We know enough about human behavior under crisis conditions to see that a recurring threat to the precarious balance between peace and war will be the desperation which is generated by the omnipresent spectre of war. Caroline Playne summarized a very original attempt to apply psychopathology to the understanding of pre-Igr4 politics in this way:

In no nation did the mass of the people consciously desire war. On the contrary, they were everywhere desperately afraid of it. . . . Nevertheless, depression deepened. ... A policy of despair-a wild desire to solve difficulties, once for all, by force, sprang up and gained possession of men's minds. The insane idea of a "war to end war" was derived from the despondency and despair which demolished reason and turned away from rational methods. ${ }^{x}$

Multitudes in all the European countries accepted the outbreak of war in IgI4, multitudes welcomed it as a licensed break-up of detestable lives. ${ }^{20}$

L. P. Jacks put the matter in a nutshell when he wrote of the "peacefulness of being at war."

Available knowledge of human response suggests, however, that we refrain from "going overboard" in estimating the factor of desperation. For the act of talking desperately is itself no inconsiderable catharsis of internal distress. Wild talk protects tame acts. Another element is the immunity of the false alarm, classically portrayed in the "wolf! wolf!" story. Persons protect themselves from feeling panicky, and making fools of themselves, by disbelieving headlines.

29 Playne, The Neuroses of the Nations 443 (1925).

${ }^{20}$ Playne, The Pre-War Mind in Britain: An Historic Review 29 (1928). 
In addition, we know of the enormously wide range of means which are at the disposal of human beings for coping with inner stress. Not the least efficacious is diversion, which consists in shifting the focus of attention from the source of frustrating subjective states. Persons who are unequipped to rely upon insight often impose upon themselves the compulsive whiplash of incessant work. Or they take up hobbies: This covers thousands upon thousands of detailed activities, from "A for Alpine climbing" to " $Z$ for zinnia raising." And there is always sexuality, conviviality, or drug addiction; and we need not overlook the many modes of physical incapacitation whose psychosomatic origin is attested by modern medicine.

One of the commonest defenses against anxiety is the denial of danger, and the reactivation of tactics which were relied upon in early life for the obviating of insecurity. The denial of danger is nearly certain to provide a rallying point for protest movements against war. Affirming that "men want peace," the prescription is to "want" peace even harder. This magical thinking can be sanctioned by invoking many heroic figures and authorities. ${ }^{2 \pi}$

Knowledge of the dynamisms of defense against anxiety does not supply us with all we need in predicting the impact of chronic crisis upon Americans. The degree of reliance upon each defense depends upon the basic patterns of the culture, position in the class structure, a sense of crisis, and the phase of personality development. At the moment we have the most rudimentary outlines of American character, of the interdependence of class and personality, of the impact of crisis, and of the detailed genesis of personality. ${ }^{22}$

Perhaps we can sum up this consideration of chronic crisis and personal insecurities by saying that while there is ample corroboration of the seriousness of desperate reactions to anxiety and uncertainty, there is ample evidence of the great range of anxiety-reducing devices. Hence there is no foundation for sweeping statements about the inevitability of war as a function of social crisis.

${ }^{2 x}$ Concerning the range of defenses against anxiety, see Fenichel, The Psychoanalytic Theory of Neurosis (x945); Freud, The Ego and the Mechanisms of Defense (1946); Jules H. Masserman, Behavior and Neurosis (1943); Dunbar, Emotions and Bodily Changes: A Survey of Literature on Psychosomatic Interrelationships (2d ed., 1938).

${ }_{22}$ Sketches of American culture, or of the American character, are found in Lynd, Knowledge for What? (1939); Mead, And Keep Your Powder Dry (1942); Kluckhohn and Kluckhohn, American Culture: Generalized Orientations and Class Patterns, in Conflicts of Power in Modern Culture (Seventh Symposium of the Conference on Science, Philosophy and Religion in Their Relation to the Democratic Way of Life) 106-28 (1947); Gorer, The Americans (I948). In general, see the approaches of Lloyd Warner, John Dollard, Ruth Benedict, Ralph Linton, and Abram Kardiner. 


\section{THE REVISION OF IDEOLOGICAL DIFFERENCES}

Our speculative model of the future forecasts the weakening of the ideological differences between the America-centered and the Russia-centered world, and the growth of a common outlook. Let us scrutinize this possibility in the light of what we know about the dynamics of ideology. ${ }^{23}$

We note, in the first place, that ideologies often change, while seeming to remain the same. This is accomplished by retaining the doctrinal skeleton intact, while modifying the details, and by changing the intensity of the emotional drives with which the skeleton is propelled into action.

Of direct interest to us are the factors which have brought about the transformation of non-cooperative policies that were buttressed by expectations of "inevitable" victory for one side. It is no novelty in human history for groups to believe in the inevitable victory of their cause and the discomfiture of their enemies. Nor is it novel to see that such claims have been accommodated to policies of peaceful cooperation with others by the gradual weakening of fanaticism and the progressive modification of doctrinal detail.

Expectations of inevitability are shaken when predictions fail. This is the most significant general truth that emerges from the comparative study of the circumstances in which ideologies of inevitability have been undermined. When the date of victory is tomorrow afternoon, and tomorrow comes and goes without the fulfillment of prophecy, a new date line is necessary, this time perhaps a more ambiguous one until eventually the millennial moment vanishes into vagueness, and remains as a figure of speech in ceremony and poetry. In our construct it is postulated that the America-centered world will succeed in preventing severe crises of mass unemployment, and hence in contraposing to the Russian doctrine a state of facts that calls for postponing the "inevitable" collapse of capitalism until well beyond tomorrow afternoon.

If the America-centered world obstinately neglects to collapse, the advantages of non-cooperation are fewer, and the burdens weigh more heavily. And these are the circumstances in which a change of line is to be expected.

The de-emphasizing of differences is favored by similarities in the doctrinal system, since these are convenient points of identification, especially when basic goal values are conceived in much the same way. It is worth remembering that there are great similarities in the doctrinal structure of Russia and America, when we take the words at face value. Both ideolo-

${ }^{23}$ Concerning ideology the writings of Karl Marx, Georges Sorel, Max Weber, Vilfredo Pareto, Gaetano Mosca, and Karl Mannheim have been influential. 
gies are democratic: They proclaim the dignity of man and the realization of the free man's commonwealth as the measure of worth and the goal of history. In a deep sense of the term both are individualistic (although this expression is in bad repute in the official semantics of Marxism): They are in unison in rejecting caste societies and in favoring mobile societies (in which individual merit counts). Both are optimistic: Cobden and Marx were equally sanguine about the imminence of a better world. Both are activistic: They expect to get results by the deliberate molding of human institutions.

The de-emphasizing of differences is favored by all other similarities of culture in addition to doctrine. And here the range of parallel experience is prodigious. Russia is in mid-stream of a vast process of industrialization, which means that Western science and technology is moving toward universality, and that certain uniformities of experience are imposed upon the attention of Russians as well as Americans, and that certain similarities of attitude will result. The modern technoscientific complex carries with it a formidable network of intercorrelated skills. Each of the universal skills begets a set of predispositions that favor universal identifications along skill lines. Physicists, chemists, biologists, astronomers, mathematicians, engineers, factory workers, mine workers, transportation workers, office workers, agricultural technicians: These and hundreds, if not thousands, of coordinate and subskill groups having an inexhaustible reservoir of common experience. Besides the work skills are the recreational skills, which can be numbered in the thousands. ${ }^{24}$

In the light of the universalizing tendencies of skill mastery, it is little wonder that parochial élites who seek to retain power on a territorial basis, find themselves constrained to adopt severe measures in holding in check the globally integrative potentialities of skill. It is the tension between the skill society and the territorial society that generates the savage repressions of insecure parochial élites, seeking to insulate their people from communion with their neighbors. ${ }^{25}$

${ }^{24} \mathrm{In}$ his monumental review of the significance of the growing recognition throughout the capitalistic world of the "human problems of industrial civilization," Georges Friedmann detects the "penetration" of other systems: "To say that the worker becomes the subject of measures of rationalization recognizes at the same time, does it not, that he is no longer a wage earner?" Problèmes humaines du machinisme industriel 344 (I946). To some extent the phenomenon is one of "penetration" of capitalism by socialism. At the same time it is direct response to the problem of obtaining production in a society with a distinctive division of labor and traditional doctrines asserting the dignity of man. The revolutionary pattern of an epoch works itself out partly by diffusion and partly by invention (and the inventions may be parallel adaptations if the same predispositions and environmental opportunities occur).

${ }^{25}$ Offsetting skill as a factor making for positive identifications must be put the influence of skill rivalry in taking advantage of whatever opportunities are perceived in a territorially circumscribed situation to gain a skill advantage. Skill identifications operate positively when the context supports expectations about the advantages of skill cooperation. 
The perpetual threat of war is itself a potentially unifying experience, for it provides a common institutional enemy as well as a personalized group enemy. The common threat and common burden create a deep implicit bond which, under circumstances of loosening tension, contributes mightily to the recovery of neighborliness, much as old combat enemies take keen delight in discovering the parallels in their own experience of weapons and fronts and officers and women. And the heat of perpetual crisis burns out the structural differences among antagonists, since each is tied to the other whom he seeks to overcome or thwart. In the degree to which the garrison state achieves universality, other institutional variations subside, until all that is left is the accident of geography that led babies to emerge from wombs in Asia rather than America. ${ }^{26}$

Revisionism, then, is possible in the ideological structure of any country, whether in the covert form of changing emotional intensities or the more overt form of doctrinal amendment. Within the traditional framework of socialism, for instance, there has been a century of struggle among the many interpreters of the methods and findings of Marx-EngelsLenin. ${ }^{27}$ And the traditional framework is well adapted to recognize new facts, since a distinction can always be made between the method of dialectical materialism and the findings of a particular writer. If the method is freshly applied to a new body of historical facts, it is capable of yielding findings that supersede earlier results. Today (and in the immediate future) there is ample room for asserting that Marx and Marxists have underestimated the influence of material factors in the present phase of industrial development. In the writing and thought of a century ago, when scientific and technological change were indescribably slower

${ }^{26}$ Among the factors that contribute to global unity are comprehensive international organizations. Such institutions, if preserved during the phase of non-cooperation, provide opportunities for the resumption of more fruitful contact later. If the opportunity is provided at recurring intervals, less intense incentives are necessary to increase the volume of cooperative association. Meanwhile propaganda on behalf of "world government" or "federal union" can serve both the power interests of the United States and the long-range interests of mankind. From the standpoint of United States power, the America-centered world is provided with a set of universal goal symbols in the name of which support can be invited from all accessible peoples (and the Soviet Union can be shown up as the great obstacle to cooperation). Furthermore, draft proposals for atomic energy control, and for the constructive use of resources, cannot postpone and may do something to expedite the coming of cooperation.

${ }^{27}$ On the richly diversified history of socialism the standard treatise remains Beer, Allgemeine Geschichte des Sozialismus und der sozialen Kämpfe, (I922-15) The full flavor of the Kautsky-Leninist controversy comes out in Kantsky, Der Bolshewismus in der Sachgasse, tr. as Bolshevism at a Deadlock (r931), and Bukharin, Karl Kautsky and Sowjet Russland, tr. from Russian (I925). See Borkenau, World Communism: A History of the Communist International (1939); Rosenberg, Democracy and Socialism (I939). Leites and de Sola Pool analyzed the response of the Communist International to frustrating conditions, and to its own changes of line, in studies published by the Division for the Experimental Study of War Communication at the Library of Congress (to be republished). 
than today, the implications of nuclear fission and jet propulsion for war were not foreseen. Today it is literally and not metaphorically true that global war can annihilate humanity, or at the very least do devastation of an unparalleled order of magnitude for large populations. Hence the forecast that the triumph of the free man's commonwealth will be ushered in by war (as the "proletarian" state repels the "imperialist" attacker) appears much less likely now than in the past.

However, it is uncertain that everyone will be annihilated in another war. Our physical scientists cannot give us conclusive assurances on this point. But even a continuing threat of war can bring about a reversal in the direction of history so that, instead of progressing from caste societies to mobile (free) societies, the new direction is from the degree of freedom already reached to the inauguration of new caste societies in the form of self-perpetuating soldier-police élites in a world of garrison-prison states.

The ideologies of the nonsocialist world have been in a bruised and battered condition in recent times, since the apologists of capitalism have been unequal to the task of arriving at a consensus on the nature of the historical process in which they find themselves. The Cobden dream of evolutionary progress to world fraternity and democracy in one big market has been rudely interrupted. It has been interrupted by the fact of giant private monopoly and the fact of global war, neither of which were foreseen or explained. When ideas fail, men also fight; and one fighting reaction of a scared non-Russian world is accepting the hope that a preventive war on Russia will put things back where they were thought to be on the evolutionary path of Cobden. But this overlooks the improbability that a preventive war will prevent anything but the peace that it destroys, since there is no credible ground for the view that our security position will be improved by "victory." (The most likely outcome, by far, is the liquidation of the businessman as a social type, and the consolidation of the garrison state.)

Given the factual situation presented by recent accelerated developments in science and technology, it is probable that the human mind will respond by adapting older ideologies to new emergencies. The issue is not socialism versus capitalism; it is far more serious than that. It is both socialism and capitalism versus the garrison-prison state (if not total, near-total annihilation of humanity).

As usual, the same revolutionary processes are working themselves out among all peoples who are in contact with one another during a given historical period, even as the "bourgeois" revolution resulted in the transformation of surviving feudal society into something else throughout the 
West. Such world revolutionary processes do not necessarily work themselves out by bringing all peoples within the framework of a single state. Nor do revolutionary transformations necessarily universalize the pattern of the revolutionary center. Rather (the bourgeois revolution is a case in point) the revolutionary pattern of the historical epoch can spread everywhere without bringing a unipolar state or conforming to the hopes and programs of the original center of revolution. The pattern of 1789 was not the pattern of the bourgeois epoch as a whole; nor did the bourgeois revolution create One Big State. In the same way, the world revolutionary processes of our time may work out in a bipolar frame, even as they depart from the aspirations of I9I 7 .

\section{SUMMARY}

We began by outlining a hypothetical course of development in which world politics preserves the peace until an eventual turning point when ordinary contact is resumed and enlarged between two bipolar garrisons.

- It is postulated that the factors in the social equilibrium which sustain the demand for cooperation always remain sufficiently strong to prevent total non-cooperation and war; and that in the fourth period, such factors of expectation and identification add greatly to the effective demand for policies of cooperation. The likelihood that events will, in fact, follow this track has been evaluated in the light of present day knowledge of the factors which affect some of the most conspicuous institutional features of the hypothetical picture. In particular, we examined bipolarity and the general theory of balance, the perils of transition to a bipolar pattern, the modes of adjusting to denials or curtailments of freedom, the factors affecting personal insecurity in times of crisis, and the factors that soften ideological differences. The result is to underline the precarious balance upon which at all times the peace depends. Among the factors making for cooperation which are to some extent within the control of policymakers and their advisors who seek democratic values is the recognition that war and chronic preparation for war can turn the course of history away from the path of progress toward freedom and back toward the restoration of caste-bound societies (if not the actual destruction of man). 